\title{
Antioxidant and Radical Scavenging Activities of Ascorbic Acid Derivatives Conjugated with Organogermanium
}

\author{
Changwon Oh, Minghua Li, Eun-Hye Kim, Jun Seok Park, Jong-Chan Lee, and Seung Wook Ham* \\ Department of Chemistry, College of Natural Science, Chung-Ang University, Seoul 156-756, Korea \\ *E-mail: swham@cau.ac.kr
}

Received August 31, 2010, Accepted September 30, 2010

Key Words: Ascorbic acid, Antioxidant effects, Organogermanium

L-Ascorbic acid, also known as vitamin C, is one of the potent naturally-occurring antioxidants in a biological system. ${ }^{1}$ Although ascorbic acid has a range of physiological and pharmacological functions, its solubility hinders its applications to reduce the reactive oxygen species (ROS) levels in vivo. Ascorbic acid is a water-soluble vitamin, and its poor liposolubility limits the cumulative amount of ascorbic acid in the cells after permeating through the cell membrane. Therefore, modification of the hydroxyl groups of ascorbic acid with long-chain fatty acids was developed to improve its liposolubility. ${ }^{2-4}$

Recently, a novel ascorbic acid derivative (Ge-Vit) conjugated with hydrophobic organogermanium was also prepared to improve the level of cell penetration. ${ }^{5,6}$ The antioxidant activity of this conjugated compound was expected to be improved by the combined effects of ascorbic acid and organogermanium because organogermaium compounds have been reported to enhance immune response, ${ }^{7}$ which may be due to its antioxidant effects. ${ }^{8}$ The results showed good radical scavenging ability and attenuation of the inflammation in vivo.
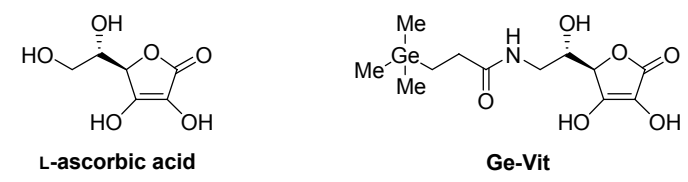

However, instability of Ge-Vit, such as the susceptibility of ascorbic acid to thermal and oxidative degradation, also makes it difficult to maintain its physiological value over long periods of time. To solve this problem, a number of stable ascorbic acid derivatives have been developed by modifying the 2-hydroxyl group of ascorbic acid. ${ }^{9-14}$ Therefore, in the present study, an organogermanium-conjugated ascorbic acid at the C-2 position was designed and investigated its antioxidant effects.

The efficient preparation of the ascorbic acid derivative conjugated with organogermaium proved to be straightforward. The acids were treated with NHS in the presence of DCC to produce the corresponding active esters 1a, b. And the vitamin $\mathrm{C}$ derivatives $\mathbf{3 a}, \mathbf{b}$ were prepared independently by reaction of ascorbic acid and the active esters $\mathbf{1 a}, \mathbf{b}$ following the literature procedure in $\sim 90 \%$ yield. ${ }^{15}$ After deprotection of the acetonide group by TFA and hydrogenolysis of the benzyl group in the presence of $\mathrm{Pd} / \mathrm{C}$, the resulting crude products were recrystallized in a hexane/ethyl acetate solution to produce the final products in good yield (Scheme 1). ${ }^{16}$

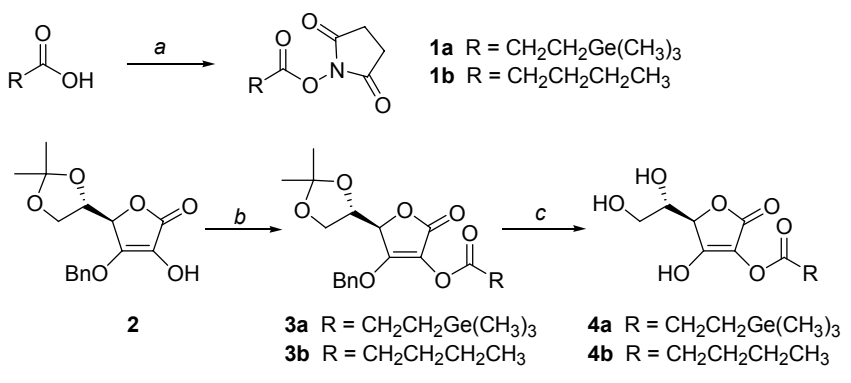

Reagents and Conditions: (a) DCC, NHS, $\mathrm{CH}_{2} \mathrm{Cl}_{2}$, rt, 16 h. (b) $1 \mathrm{a}$ or 1b, $\mathrm{K}_{2} \mathrm{CO}_{3}$, Acetone, $50{ }^{\circ} \mathrm{C}, 16 \mathrm{~h}$. (c) TFA, $10 \% \mathrm{Pd} / \mathrm{C}, \mathrm{H}_{2}$, EtOH, rt, $4 \mathrm{~h}$.

Scheme 1. The synthetic routes to the ascorbic acid derivatives (4a, 4b) conjugated with organogermanium

Table 1. Radical scavenging activity of ascorbic acid and its derivatives against DPPH

\begin{tabular}{ccc}
\hline Compound & $\begin{array}{c}\text { Scavenging Activity }(\%) \\
\text { at } 0.1 \mathrm{mM}\end{array}$ & $\mathrm{EC}_{50}(\mu \mathrm{M})$ \\
\hline Ascorbic Acid & $89.3 \pm 0.4$ & $23 \pm 1$ \\
4a & $62.5 \pm 0.9$ & $60 \pm 2$ \\
4b & $19.0 \pm 0.9$ & - \\
\hline
\end{tabular}

The free radical scavenging activity of the ascorbic acid derivatives was then measured using a DPPH assay reported in the literature. ${ }^{17}$ When the scavenging activity of each compound was quantified by the decolorization of DPPH at $516 \mathrm{~nm}$ after 30 min-incubation at $25^{\circ} \mathrm{C}$, compound $4 \mathbf{a}$ exhibited radical scavenging activity, even though its activity was lower than that of ascorbic acid (Table 1). Stable 2-O-substituted ascorbate derivatives generally have little scavenging effect. ${ }^{4}$ This result also shows that ascorbyl 2-pentanoate $\mathbf{4 b}$ has only limited activity, indicating that the radical scavenging effect was caused by the germanium core of compound $4 \mathbf{a}$. The $\mathrm{EC}_{50}$ values $(50 \%$ of the absorbance shown by a blank test) of vitamin $\mathrm{C}$ and compound $4 \mathrm{a}$ were 23 and $60 \mu \mathrm{M}$, respectively. In contrast, the $\mathrm{EC}_{50}$ of ascorbyl 2-pentanoate could not be determined, indicating that the radical scavenging activity is extremely weak. Although ascorbic acid and Ge-Vit decomposed almost completely within 1 day, ${ }^{1} \mathrm{H}$ NMR analysis showed that compounds 4a remained stable for more than 1 month in distilled water at room temperature. Accordingly, compound 4a continuously showed radical scavenging ability for 2 days at $37{ }^{\circ} \mathrm{C}$, whereas compound $4 \mathrm{~b}$ produced limited scavenging activity (Figure 1 ). 


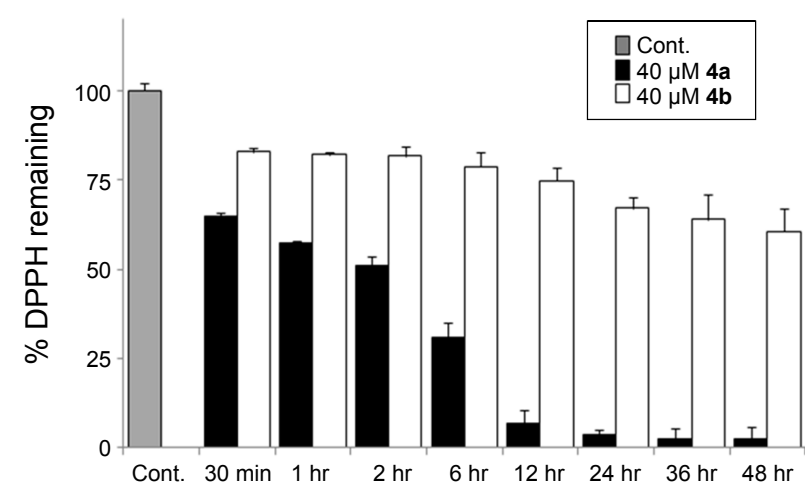

Figure 1. Time course of radical scavenging activity of $4 \mathbf{a}$ and $\mathbf{4 b}$ at $37^{\circ} \mathrm{C}$.

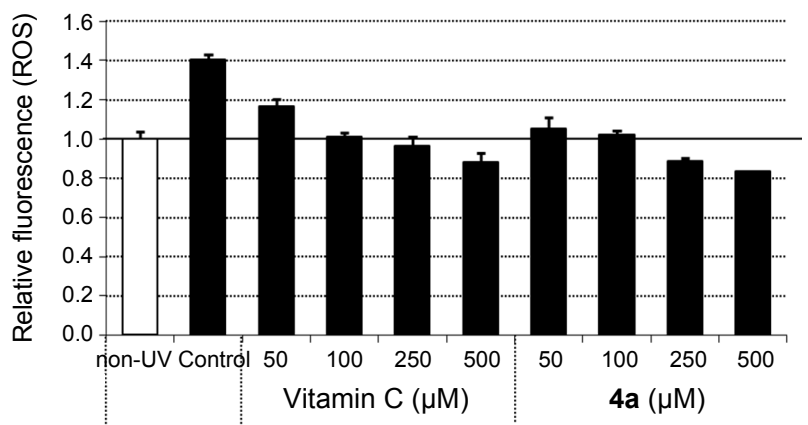

Figure 2. Antioxidant activities of $\mathbf{4 a}$ using $\mathrm{H}_{2}$ DCF-DA dye system in $\mathrm{HaCaT}$ cells.

Ascorbyl 2-palmitate, which is one of lipophilic and stable 2-O-substituted ascorbate derivatives, showed vitamin $\mathrm{C}$ activity in vitro and in vivo after enzymatic hydrolysis to free vitamin C by a certain esterase. ${ }^{4}$ Therefore, to determine the cellular anti-oxidant effect of the compounds in the skin model, their protective effects against UV damage on the keratinocyte cell line, $\mathrm{HaCaT}$, was examined using a $\mathrm{H}_{2} \mathrm{DCF}-\mathrm{DA}$ dye system employing a fluoreoscent assay after determining the cytotoxic potential of the compounds. ${ }^{18}$ As shown in Figure 2, the amount of ROS in the UVB-treated cells produced a $\sim 40 \%$ increase compared to the non-treated control cells. When UVB-treated cells were treated with the compounds, compound 4a induced a significantly larger dose-dependent increase in antioxidant capacity of the cells, whereas ascorbic acid showed relatively less anti-oxidant potency. This result indicated that might exhibit the increased antioxidant effect in vivo by vitamin $\mathrm{C}$ and organogermanium after enzymatic hydrolysis.

In summary, a stable lipophilic organogermanium-conjugated ascorbic acid derivative with the combined effects of ascorbic acid and organogermanium was prepared. The DPPH assay revealed this compound to have good radical scavenging activity.
This compound also induced a significantly larger dose-dependent increase in the antioxidant capacity of the cells according to the $\mathrm{H}_{2}$ DCF-DA dye system. The cell viability of $\mathrm{HaCaT}$ cells determined by a MTT assay revealed the compounds to have no cytotoxicity within the given concentration range (up to 10 $\mathrm{mM}$ ), suggesting that the compounds are not cytotoxic to cells. Therefore, amphiphilic organogermanium-conjugated ascorbic acid would be a useful pharmaceutical material both in vitro and in vivo.

Acknowledgments. This research was supported by the Chung-Ang University Research Scholarship Grants in 2010.

\section{References}

1. Wilson, J. X. Annu. Rev. Nutr. 2005, 25, 105.

2. Nishio, K.; Morikage, T.; Ohmori, T.; Kubota, N.; Takeda, Y.; Ohta, S.; Yazawa, K.; Saijo, N. Proc. Soc. Exp. Biol. Med. 1993, 203, 200.

3. Watanabe, Y.; Fang, X.; Minemoto, Y.; Adachi, S.; Matsuno, R. J. Agric. Food Chem. 2002, 50, 3984.

4. Fujinami, Y.; Tai, A.; Yamamoto, I. Chem. Pharm. Bull. 2001, 49. 642 .

5. Lim, D. H.; Li, M.; Seo, J. A.; Lim, K. M.; Ham, S. W. Bioorg. Med. Chem. Lett. 2010, 14, 4032.

6. Lim, D. H.; Li, M.; Kim, E.; Ham, S. W. Bull. Korean Chem. Soc. 2010, 31, 1839.

7. Brutkiewicz, R. R.; Suzuki, F. In Vivo. 1987, 1, 189.

8. Wakabayashi, Y. Biosci. Biotechnol. Biochem. 2001, 65, 1893.

9. Mead, C. G.; Finamore, F. J. Biochemistry 1969, 8, 2652.

10. Mumma, R. O.; Verlangieri, A. J. Biochim. Biophys. Acta 1972, 273,249

11. Jernow, J.; Blount, G. J.; Oliveto, E.; Perrotta, A.; Rosen, P.; Toome, V. Tetrahedron 1979, 35, 1483.

12. Kato, K.; Terao, S.; Shimamoto, N.; Hirata, M. J. Med. Chem. 1988, 31, 793.

13. Yamamoto, I.; Muto, N.; Murakami, K.; Suga, S.; Yamaguchi, H. Chem. Pharm. Bull. 1990, 38, 3020.

14. Shibayama, H.; Hisama, M.; Matsuda, S.; Kawase, A.; Ohtsuki, M.; Hanada, K.; Iwaki, M. Biosci. Biotechnol. Biochem. 2008, 74,1015

15. Gazivoda, T.; Wittine, K.; Lovric, I.; Kakuc, D.; Plavec, J.; Cetina, M.; Mrvos-Sermek, D.; Suman, L.; Kralj, M.; Pavelic, K.; Mintas, M.; Raic-Malic, S. Carbohyd. Res. 2006, 341, 433.

16. $4 \mathbf{4 a} ; \mathrm{mp} 85.3-91.7^{\circ} \mathrm{C}$; IR (neat) $\mathrm{cm}^{-1}: 2951,2887,1743,1631 ;{ }^{1} \mathrm{H}$ $\operatorname{NMR}\left(\mathrm{D}_{2} \mathrm{O}\right) \delta 4.98(\mathrm{~s}, 1 \mathrm{H}), 4.10(\mathrm{~d}, J=7.9,2 \mathrm{H}), 3.77(\mathrm{~d}, J=7.0$, $1 \mathrm{H}), 2.74-2.64(\mathrm{~m}, 2 \mathrm{H}), 1.11-0.99(\mathrm{~m}, 2 \mathrm{H}), 0.15(\mathrm{~d}, J=6.8,9 \mathrm{H})$; ${ }^{13} \mathrm{CNMR}\left(\mathrm{D}_{2} \mathrm{O}\right) \delta 179.29,179.10,175.89,175.73,159.18,121.42$, 115.68, 81.19, 72.66, 65.61, 32.49, 14.03, $-0.00 .4 \mathrm{~b}$; IR (neat) $\mathrm{cm}^{-1}$ : 2952, 2919, 1761, 1724, 1662; ${ }^{1} \mathrm{H}$ NMR $\left(\mathrm{D}_{2} \mathrm{O}\right) \delta 5.04-4.92(\mathrm{~m}$, $1 \mathrm{H}), 4.18(\mathrm{~s}, 1 \mathrm{H}), 3.80-3.69(\mathrm{~m}, 2 \mathrm{H}), 2.60(\mathrm{t}, J=7.3,2 \mathrm{H}), 1.79-1.58$ $(\mathrm{m}, 2 \mathrm{H}), 0.98(\mathrm{dd}, J=13.9,7.4,3 \mathrm{H}) ;{ }^{13} \mathrm{C}$ NMR $\left(\mathrm{D}_{2} \mathrm{O}\right) \delta 170.78$, 169.39, 163.94, 113.10, 77.81, 71.20, 61.66, 34.49, 17.72, 12.38.

17. Quéléver, G.; Kachidian, P.; Melon, C.; Garino, C.; Laras, Y.; Pietrancosta, N.; Sheha, M.; Louis, K. J. Org. Biomol. Chem. 2005, 3,2450 .

18. El Hindi, T.; Ehlers, G.; Demchuk, M.; Pfitzner, I. Arch. Dermatol. Res. 2004, 296, 258. 